\title{
Growth factors in inflammatory bowel disease
}

\author{
NICHOLAS WRIGHT MA MD PhD DSc FRCPath
}

\begin{abstract}
N Wright. Growth factors in inflammatory bowel disease. Can J Gastroenterol 1996;10(3):191-198. Growth factors have many influences on the gastrointestinal tract, not just modulating cell proliferation, but also acting on other aspects of physiology. Several of these functions are incriminated in the pathogenetic and healing phenomena that accompany inflammatory bowel disease (IBD). A review of growth regulation in the intestine is presented. Topics include growth phenomena in IBD, sources of growth factors, growth factors in gut growth responses, trefoil peptides, other growth factors and role of growth factors in IBD.
\end{abstract}

Key Words: Growth factors, Inflammatory bowel disease, Review

Qeveral morphological changes can be discerned in $\checkmark$ the spectrum of inflammatory bowel disease (IBD), encompassed by the general processes of cell proliferation and differentiation. Examples are the mucosal hyperplasia that accompanies ulcerative colitis, where colonic crypts lengthen and undergo increased crypt fission, the mucin cell depletion also found in ulcerative colitis and the several metaplasias, such as pyloric metaplasia in Crohn's disease, and Paneth's cell metaplasia, most common in ulcerative colitis. It is therefore relatively easy to manufacture a slot for the study of growth control in understanding the pathogenesis of IBD.

Knowledge of growth regulation in the intestine is at an

\section{Facteurs de croissance dans la maladie inflammatoire de l'intestin}

RÉSUMÉ : Les facteurs de croissance exercent de nombreuses influences sur les voies digestives et ne font pas que moduler la prolifération cellulaire, puisqu'ils agissent sur d'autres aspects de la physiologie. Plusieurs autres de ces fonctions sont incriminées dans les phénomènes pathogéniques et cicatriciels qui accompagnent la maladie inflammatoire de l'intestin (MII). Un survol de la régulation de la croissance dans l'intestin est présenté ici. Les thèmes abordés sont entre autres : les phénomènes de croissance dans la MII, les sources des facteurs de croissance, les facteurs de croissance dans la réponse de croissance de l'intestin, les peptides «trefoil», autres facteurs de croissance et rôle des facteurs de croissance dans les MII.

Department of Histopathology, Royal Postgraduate Medical School, Hammersmith Hospital, Du Cane Road, and Histopathology Unit, Imperial Cancer Research Campaign Laboratories, Lincoln's Inn Fields, London, United Kingdom

Correspondence: Dr N Wright, Department of Histopathology, Royal Postgraduate Medical School, Hammersmith Hospital, Du Cane Road, London W12 0NN, United Kingdom. Telephone 181-740-3292, fax 181-740-7417, e-mail jgarnet@rpms.ac.uk

This paper was presented at the Basic Research and Clinical Implications in IBD meeting, April 6 to 9, 1994, held in Victoria, British Columbia. This paper has also been published in Sutherland LR, et al, eds. Inflammatory Bowel Disease: Basic Research, Clinical Implications and Trends in Therapy. Boston, Dordrecht and London: Kluwer Academic Publishers, 1994 


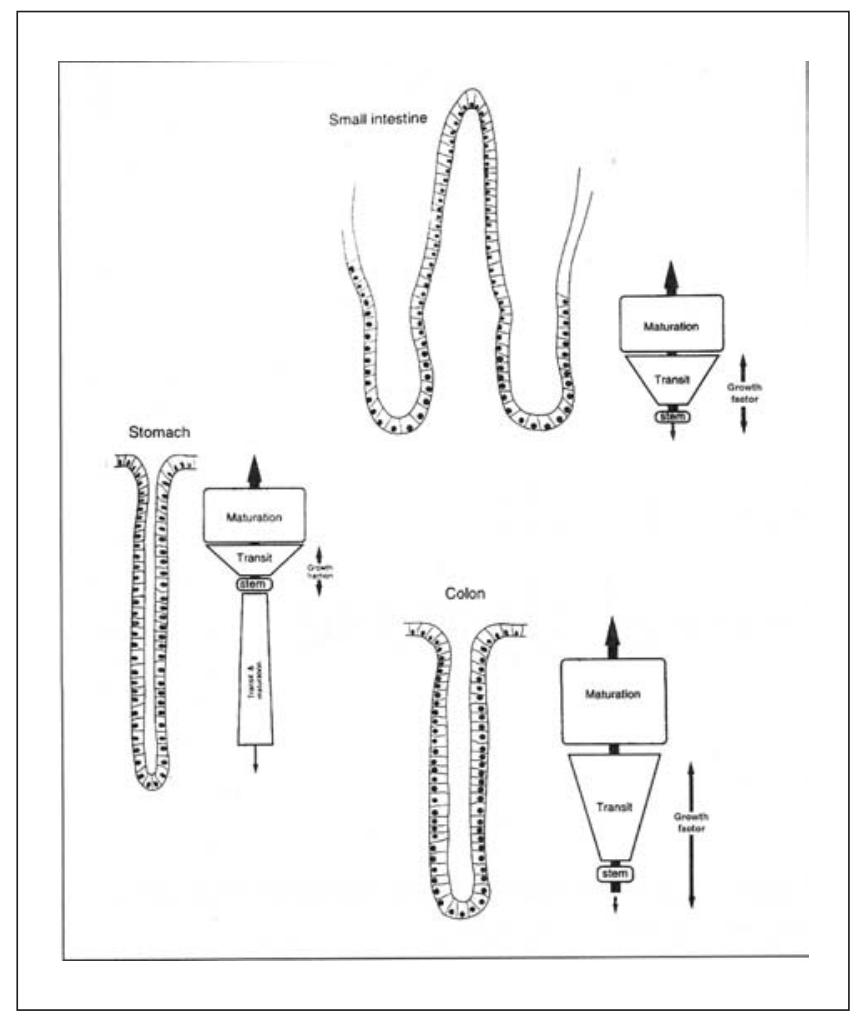

Figure 1) Classical concept of the organization of cell proliferation in the crypt systems of the gut

single stem cell, was conceived long ago by Cheng and Leblond (2) for the small bowel and by Chang and Leblond (3) for the colon, but definitive proof was lacking until studies involving tetraparental allophenic chimeric mice (4) and associated crypt-restricted lectin binding, and mice heterozygous for an X-chromosome-linked enzyme defect (glucose-6-phosphate dehydrogenase) (5). Such cryptrestricted markers in these models show that Paneth, columnar and goblet cell lineages are clonal, but that the clonality of gut endocrine cells is only shown by using male:female allophenic chimeric mice (6), in effect the final nail in the neural crest component of the all-encompassing amine precursor uptake and decarboxylation cell hypothesis (7).

The crypt stem cell feeds the proliferative compartment of the crypt, where the stem cell efflux is amplified, and subsequently cells cease division and migrate onto the surface to coat the villi in the small intestine and the surface of the colon as functional enterocytes and colonocytes.

Intestinal cells are well known for their rapid rate of proliferation, one of the highest in the human body. Nevertheless, the system remains adaptive, undergoing circadian variation (1) and responding to different physiological and, of course, pathological conditions. Intestinal adaptation has perhaps been best studied by partial resection, after which the remnant undergoes considerable hyperplasia (1). As well as exhibiting hyperplastic phenomena, the intestine also adapts to decreased workload during starvation or total parenteral nutrition (TPN) by reducing its rate of cell production.

\section{GROWTH PHENOMENA IN IBD}

In ulcerative colitis there is an increase in the rate of crypt cell proliferation, not only in the mucosa surrounding the ulcers, but also in the mucosa between the ulcers (8). This results in lengthening of the colonic crypts. There is also an increase in the rate of crypt fission, which can result in as many as $30 \%$ of crypts dividing in ulcerative colitis. There are also changes in the cytology of the crypts, with a reduction in the numbers of mucin-secreting goblet cells. While there is an increased rate of production of goblet cells in experimental colitis with goblet cell depletion, there is also an increased rate of mucin discharge so that goblet cells cannot be recognized in tissue sections (8). In the later stages of both ulcerative colitis and Crohn's disease there is also an increased risk of dysplasia and carcinoma (9).

Other changes in crypt cytology include Paneth cell 'metaplasia' which is found in the colon, especially in ulcerative colitis. Also, in ulcerative colitis, but especially in Crohn's disease and particularly in the small bowel, cells resembling pyloric cells appear in the mucosa ('pyloric' or 'pseudopyloric' metaplasia). The life history and function of these cells have recently been traced, and they are a source of several modulating peptides that have considerable trophic effects in the regenerating mucosa (10) (see below).

In IBD there is a considerable infiltrate of both mononuclear and polymorphonuclear cells in the lamina propria and associated hyperplasia of mucosal lymphoid tissue.

\section{SOURCES OF GROWTH FACTORS}

Circulating hormones: Circulating hormones can modulate growth responses in the gut. Older literature documents effects of 'classical' hormones such as corticosteroids, thyroxine, growth hormone and insulin on cell proliferation in the intestine; however, their importance in the pathogenesis of IBD is difficult to discern, apart from the obvious reduction in proliferative rate induced by corticosteroids which may be important therapeutically (11). But there is a considerable body of evidence that supports the hypothesis that circulating hormones, probably of intestinal origin, are important in inducing adaptive responses in the gut. The minutiae of this complex field is summarized by Williamson $(12,13)$, but the critical experiments are probably:

- that partial intestinal resection of one animal in a pair of rats joined in cross-circulation (not parabiosis) results in induced cell proliferation in the intestine of the unoperated partner (14);

- that Thirty-Vella loops, isolated from the normal fecal stream, show proliferative responses when the animals are fed orally but not when fed by TPN (15), and show proliferative responses after resection of the intestine in continuity (16), and;

- that infusion of hypertonic glucose into the rectum of rats leads to the induction of cell proliferation in the small intestine (17). 
The identity of the circulating hormone and its source is not clear; suspicion has fallen on enteroglucagon as the candidate hormone (18), but definitive proof is lacking.

Luminal factors: Food in the gut lumen is a potent stimulus of cell proliferation. The exact nature of this so-called 'luminal nutrition' has defied explanation for some time whether the epithelial cells need a constant supply of absorbed nutrients for sustained proliferation (19), whether some nutrients (for example, polyamines, glutamine and short chain fatty acids [SCFA], the fermentation products of soluble fibre, which also influence growth, see below) are responsible, whether the induction of a 'functional demand' in the form of increased mucosal workload by absorption/secretion (19) is operative or whether luminal contents evoke trophic gut hormone or growth factor release is unclear.

Certainly absence of food in the lumen leads to prominent mucosal atrophy; this is not due to overall calorie malnutrition because such atrophy still occurs when animals are fed intravenously (20). There is also evidence that individual nutrients infused into isolated loops or Thirty-Vella fistulas induce local cell proliferation, namely elemental diets, glucose, disaccharides and amino acids. Such induction may be independent of substrate, and thus transport alone may be the inducer of cell proliferation (19).

Specific luminal molecules may act as growth factors for the epithelium. Polyamines have a potent effect on the growth of the intestinal mucosa $(21,22)$. The production of polyamines is rate-limited by the enzyme ornithine decarboxylase (ODC), and inhibition of ODC leads to abrogation of epidermal growth factor (EGF)-induced cell proliferation in the small intestine (23) and to hypoplasia, as well as to a reduction in the proliferative response to other hyperplastic stimuli $(23,24)$. Polyamines in the lumen may increase expression of ODC, increasing the production of spermine and spermidine which stimulate cell proliferation (24). Epithelial cells in the small intestine can use polyamines (25), and infusion of putrescine, a further polyamine, increases rat mucosal growth (26). Other molecules with designated trophic actions include SCFA and glutamine. The well known stimulation of cell proliferation in the rat colon caused by dietary fibre has been shown to be due to its fermentation, which produces SCFA (27), and to direct luminal infusion of SCFA (27).

Hormones/growth factors induced by luminal contents: The presence of food in the lumen may induce secretion of gut hormones and/or growth factors, which stimulates growth and, hence, maintains mucosal mass. There is no doubt, for example, that feeding induces secretion of enteroglucagon, the candidate enterotrophin, and other candidate hormones in both animals and humans (28). The direct trophic action of these hormones is yet to be determined.

Perhaps more reliable is the report that luminal contents can induce the expression of genes that encode for growth factors known to stimulate cell proliferation in the gut (29). Dietary fibre has been shown to stimulate rat colonic cell proliferation (27); Figure 2 shows the relationship between dietary fibre type and cell proliferation in the rat colon, and

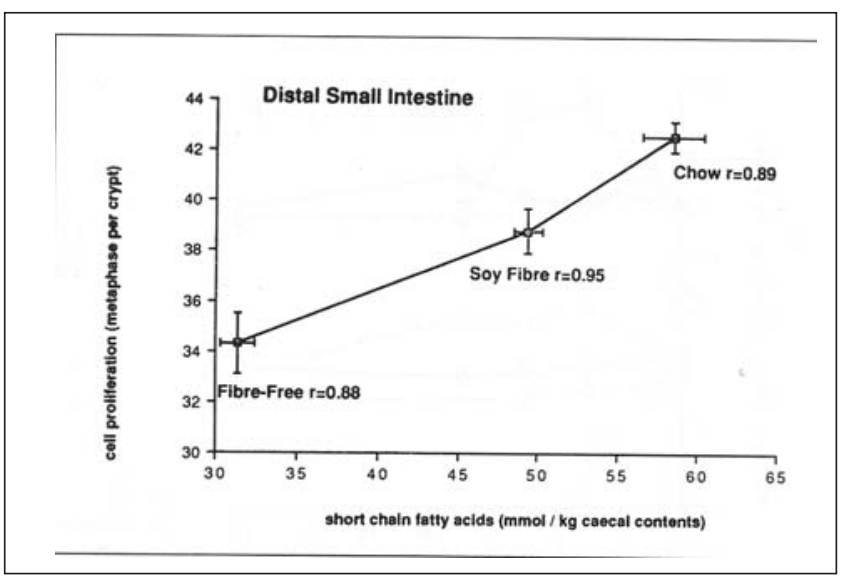

Figure 2) Relationship between the rate of crypt cell production in the rat colon, here represented by the crypt cell production rate, and the ingestion of different types of dietary fibre

Figure 3 shows that this induction of cell proliferation is associated with increased EGF and transforming growth factoralpha (TGF $\alpha)$ gene expression. It is thus clear that luminary-directed growth responses in the gut are associated with growth factor gene expression.

A consideration of these growth factors in gut growth responses follows.

\section{GROWTH FACTORS IN GUT GROWTH RESPONSES - EGF/TGF $\alpha$}

EGF and TGF $\alpha$ are members of a growing group of molecules that include EGF, TGF $\alpha$, amphiregulin and heparinbinding EGF; there are other homologues such as cripto. Their commonality lies in the possession of six cysteine residues that form three disulphide bonds, resulting in highly stable molecules. Both EGF and TGF $\alpha$ are initially elaborated as membrane-bound molecules; pro-proEGF has a 24 amino acid signal peptide on its amino terminal, and a membrane-bound 25 residue hydrophobic domain on the $\mathrm{C}$-terminal end. TGF $\alpha$ also has this membrane-spanning domain, and it is clear that both EGF and TGFa have to be enzymatically released from the membrane-bound state to be secreted. However, TGF $\alpha$ can act in a juxtacrine manner when still attached to the membrane, although the evidence for EGF acting in this manner is scant. There is little known about the regulation of EGF gene expression, but the upstream elements of the TGF $\alpha$ gene show SP1 and AF2 binding sites.

Both EGF and TGFa bind the EGF receptor (EGFR), a $150,000 \mathrm{kDa}$ membrane-spanning molecule with a ligandbinding extracellular domain, a hydrophobic transmembrane domain and an intracellular domain with tyrosine kinase activity. Ligand-receptor binding results in autophosphorylation and possible nuclear translocation. While there are some differences between EGF and TGFa in affinity for the EGFR, their functional effects are remarkably similar.

EGF, a secreted molecule in the gastrointestinal tract, is found in upper gastrointestinal secretions and can be localized to the salivary glands, the mucous neck cells of the gas- 


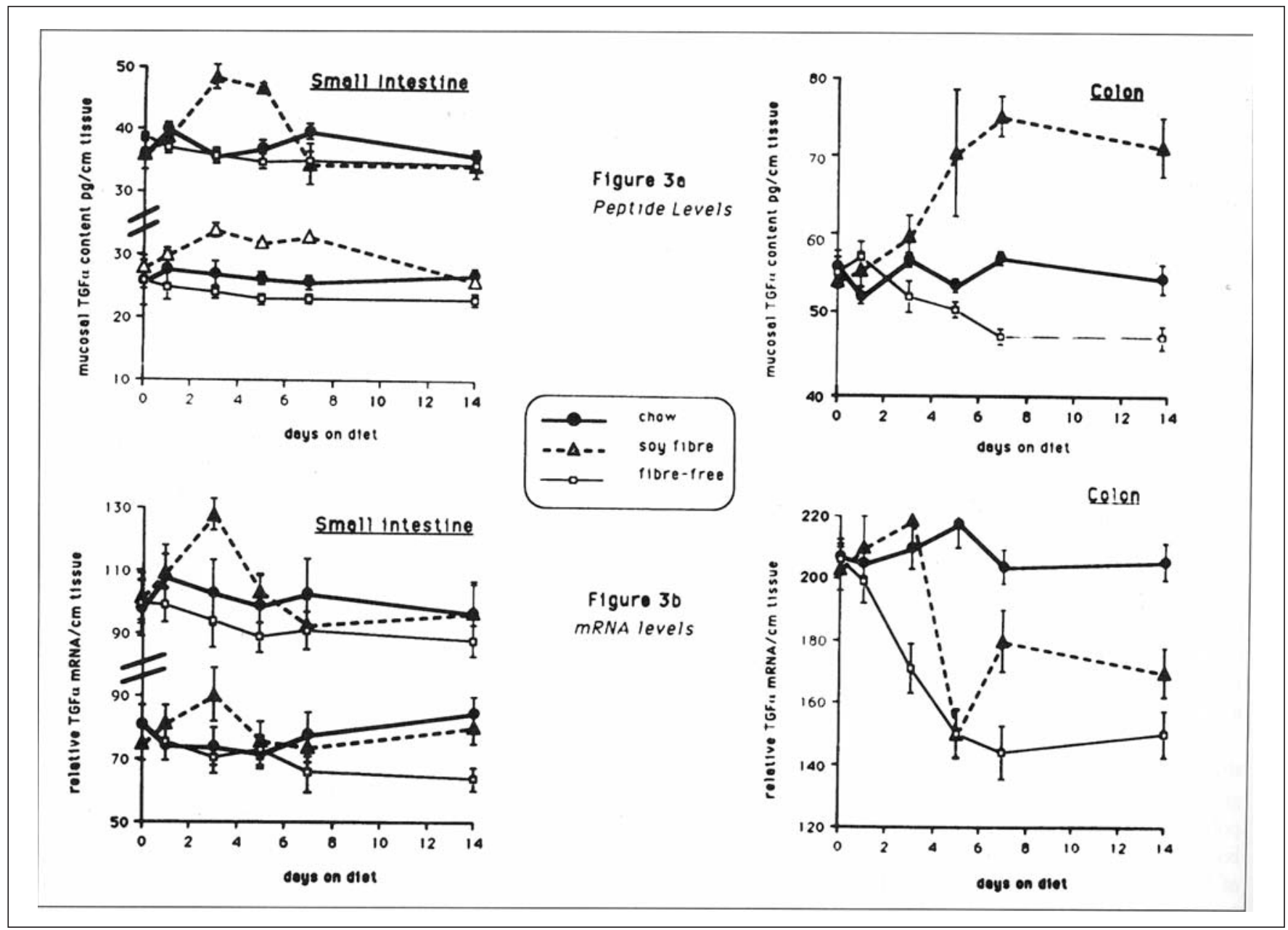

Figure 3) Effects of different types of fibre on epidermal growth factor and transforming growth factor-alpha (TGF $\alpha$ ) $m R N A$ and peptide levels in the small intestine and colon of the rat

tric mucosa and the mucus-secreting acini of Brunner's glands; there is little evidence for EGF secretion elsewhere in the gut (but refer to Figure 3). EGF is also present in maternal milk (30). It is therefore important to ask whether EGF acts luminally. EGF receptors are found both on the apical enterocyte surface and on the basolateral surface. In the neonate, there are EGF-modulated effects evoked by luminally administered EGF (31). In the calf there is evidence that the apical EGFR is not phosphorylated by EGF ligand-receptor binding, although the basolateral receptors are, but Thompson (32) has recently shown that luminal EGF binds EGFR and neu on the apical surface in neonatal rat intestine, resulting in phosphorylation of both these receptors. Nevertheless, certainly in the adult animal (33) and possibly in the neonate (31), EGFRs are concentrated on the basolateral surface. This distribution implies that EGF must be transported intact across the mucosa to have an effect. While there is limited evidence for intact EGF being taken up by the neonatal rat ileum (34), in that study (34) most EGF is degraded. It has also been anticipated that EGF would be degraded in the mature intestine (35), but it has been suggested that the pancreatic secretory trypsin inhibitor, secreted not only by the pancreas but also by the mucous neck cell lineage in the stomach, and evoked by luminal contents, protects EGF in the intestinal lumen.

The evidence for luminal activity of EGF in mature animals, however, is mixed - certainly infusion into defunctionalized colonic segments also stimulates cell proliferation (36). Goodlad and colleagues (37) failed to show any action of luminal EGF in animals maintained on TPN, even at high doses, whereas when lower doses given intravenously were used, the authors were able to replicate levels of cell proliferation seen in intact, fed, control animals. Moreover, the acid-inhibitory action of EGF seen after intravenous infusion is not evoked by intragastric or intrajejunal infusion (38).

These studies suggest that EGF may need mucosal damage to bind its receptor; certainly orally administered iodinated EGF does not bind to intact rat gastrointestinal mucosa, but does bind locally around areas of mucosal damage. In IBD, especially Crohn's disease, EGF can be produced by a cell lineage, the so-called 'ulcer-associated cell lineage' (UACL), which grows adjacent to the chronic ulcers (Figure 4) (10).

TGF $\alpha$, on the other hand, is found throughout the gastro- 


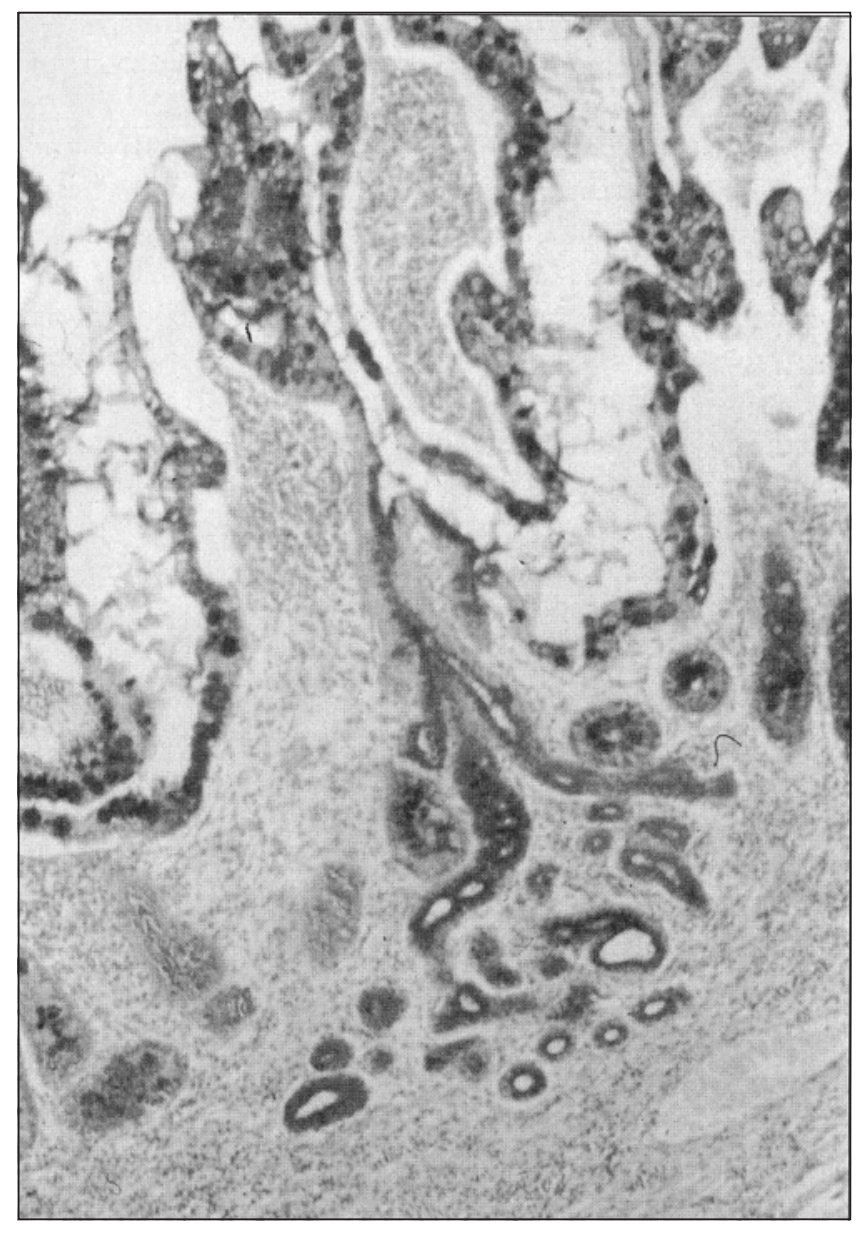

intestinal mucosa (39) and occupies the differentiated cell compartment in the small intestine and villus epithelium. Nevertheless, there is evidence that TGF $\alpha$ stimulates gut epithelial cell proliferation. There is little information on how TGFa localizes to and binds the EGFR.

While many studies concentrate on the growth-promoting properties of EGF/TGF $\alpha$, it should be stressed that noncell cycle-related genes are also regulated. For example, EGF stimulates electrolyte and nutrient transport in the gut (40), up-regulating brush border enzyme activity (31), and enhances pS2 (a trefoil peptide, see below) gene expression (41).

\section{GROWTH FACTORS IN GUT GROWTH RESPONSES - TRANSFORMING GROWTH FACTOR-BETA}

The transforming growth factor-beta (TGF $\beta$ ) family, whose actions were first described as a 'transforming activity' that induced anchorage-independent growth in a nonneoplastic cell line $(42,43)$, is a series of related molecules, TGF $\beta$ 1-5. In mammals the main classes of TGF $\beta$ are TGF $\beta$ 1-3. These are synthesized as large precursor molecules and processed to yield $12.5 \mathrm{kDa}$ mature monomers. However, the sequence of events that leads to homodimeric peptide secretion has not yet been fully worked out. There are at least three classes of TGF $\beta$ receptor.

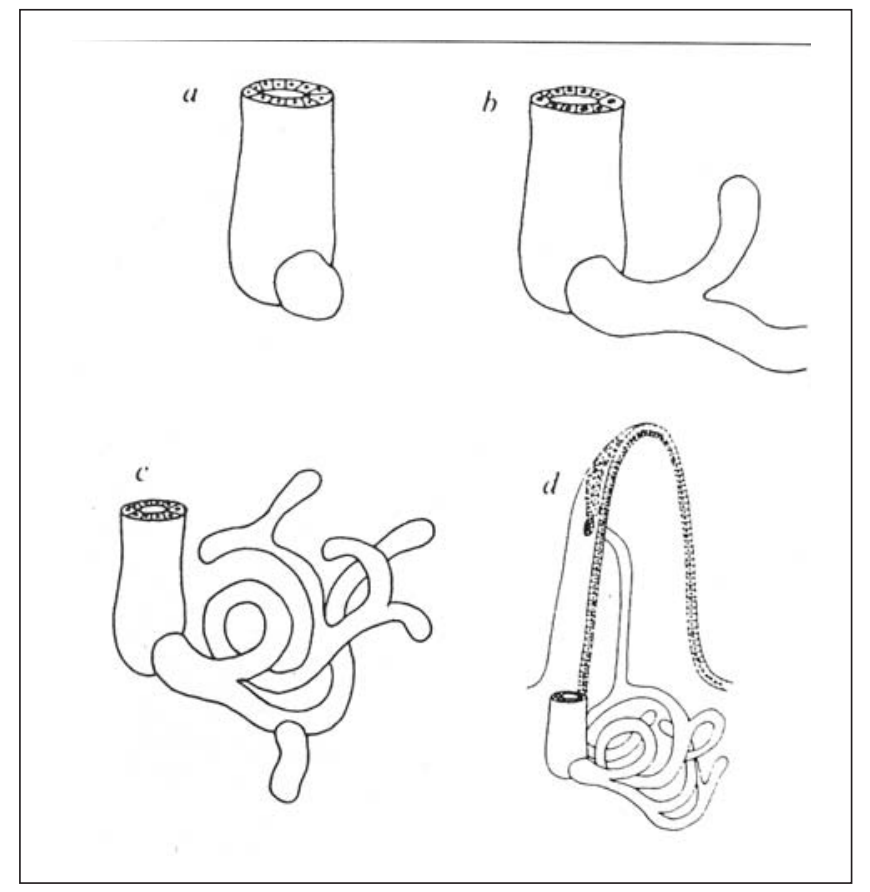

Figure 4) Above Diagrammatic representation of the histogenesis of the ulcer-associated cell lineage (UACL). Left Photomicrograph of the mature UACL system. The condition is Crohn's disease. Note the acini, the duct and the cells emerging onto the villus surface replacing the indigenous cell lineages

TGF $\beta$ has several functions that make it potentially a very important molecule in IBD: it inhibits epithelial cell proliferation (44); it affects differentiation of colorectal carcinoma cells $(45,46)$; and it has important actions on the synthesis of extracellular matrix proteins, increasing synthesis of the collagens (fibronectin, tenascin and elastin), decreasing synthesis of collagenases, stromelysin and plasminogen activators, and increasing synthesis of protease inhibitors such as tissue inhibitor of metalloproteinase and plasminogen activator inhibitor (47). Thus, in a very complex manner, TGF $\beta$ induces formation of extracellular matrix and affects its composition. Moreover, TGF $\beta$ can act as an 'indirect mitogen' for mesenchymal cells, possibly upregulating platelet-derived growth factor expression (48).

TGF $\beta$ also acts on immune function, inhibiting both $T$ and $B$ cell growth, reducing immunoglobulin production and natural killer cell activity, and modulating cytokine production, reducing the synthesis of interleukin 1, 2 and 3 (47). TGF $\beta$ is also a powerful attractant for monocytes, fibroblasts and neutrophils (47) in femtomolar concentrations. In this manner TGF $\beta$ also stimulates cell migration in IEC-6 cells (an intestinal cell line) after 'wounding' a monolayer of these cells in vitro while cell proliferation was inhibited (49); this action was inhibited by anti-TGF $\beta$ antiserum. This suggests a role for TGF $\beta$ in promoting epithelial restitution after mucosal damage. 

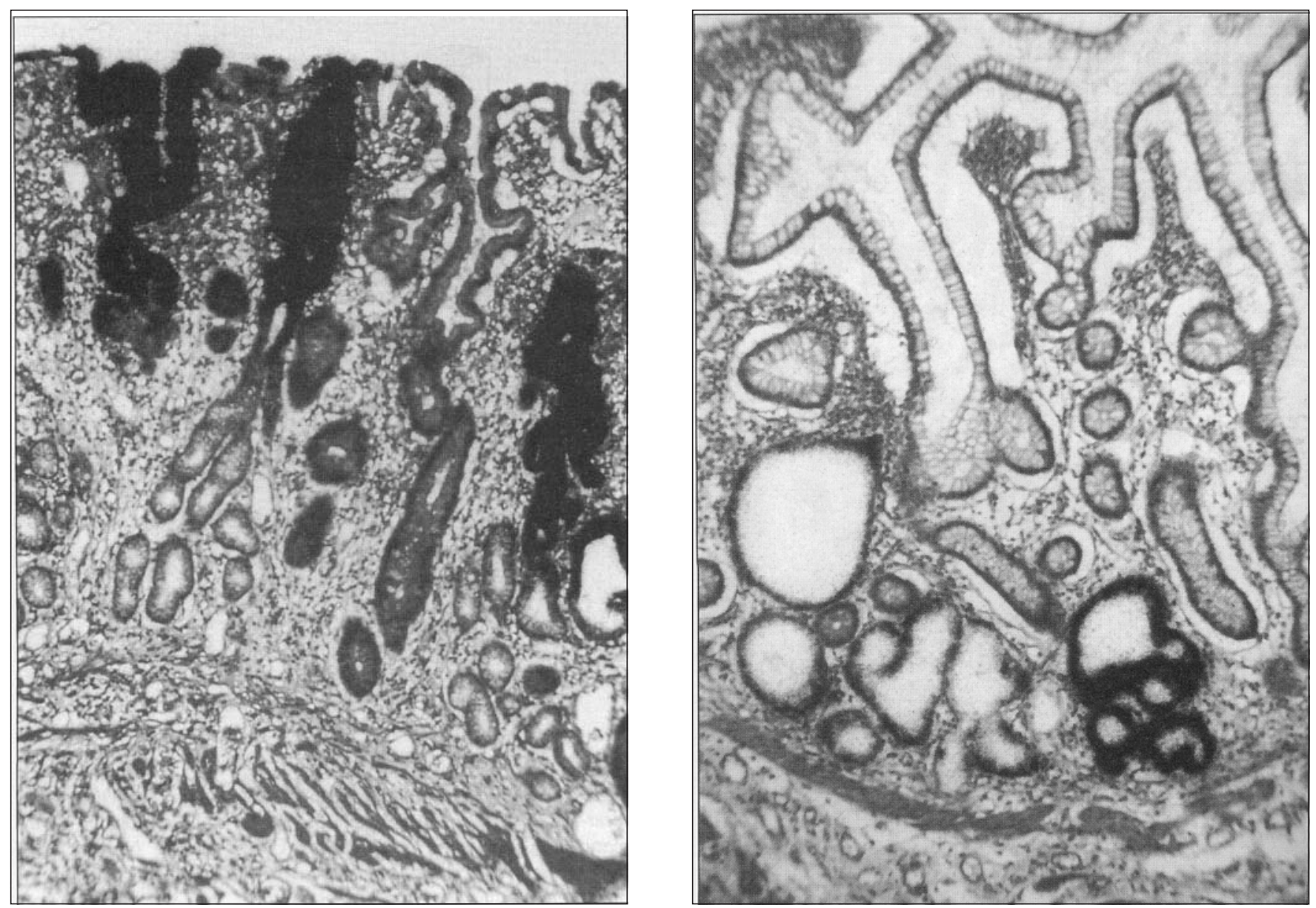

Figure 5) Distribution of (left) pS2 mRNA and (right) hSP mRNA in the ulcer-associated cell lineage as demonstrated by in situ hybridization using $35 S$ riboprobes

TGF $\beta$ 1-3 are found in the intestine, both in crypt epithelial cells and in the lamina proprial cell populations. Thus these molecules have a potentially important role in IBD.

\section{TREFOIL PEPTIDES}

Trefoil peptides are a series of related molecules that are characteristically secreted by mucus-secreting cells. Their common characteristic is a three-looped structure strongly held by disulphide bonds based on six intramolecular cysteine residues. The three-dimensional structure of these molecules has recently been worked out using a combination of $\mathrm{x}$-ray crystallographic and nuclear magnetic resonance methods $(50,51)$. Trefoil peptides exist in mammalian tissues as single trefoil domain peptides, such as pS2 which is found in the gastric epithelium, and as intestinal trefoil factor (ITF) which is usually localized to the intestinal goblet cells. These peptides also exist as two-domain molecules, such as spasmolytic polypeptide (SP), first described by Thim et al (52) in pig pancreas, but which has also been localized in humans in mucous neck and foveolar cells of the gastric mucosa, antral mucus-secreting glands, and Brunner's gland acini and ducts.

The functions of these peptides is not yet clear. pSP has been reported to inhibit gastric acid secretion and intestinal muscular activity (53). However, recent results have not confirmed this latter action (personal communication). There have been reports that pSP stimulates the growth of colorectal carcinoma cells in vitro, but this action is singular in being glutathione-dependent (personal communication), and there does not appear to be any effect when infused into rats maintained on TPN (personal communication). However, ITF appears to have an action on electrogenic chloride transport in the rat small intestine and to be a powerful stimulant of cell migration in epithelial monolayers 'wounded' in vitro (personal communication). Moreover, hSP has been shown to stimulate epithelial restitution after indomethacin-induced damage in the rat stomach (personal communication). These molecules may be involved in the organization of the viscoelastic mucus layer. These molecules are abundant and very resistant to degradation, and their function in the gut is therefore important to resolve.

\section{OTHER GROWTH FACTORS}

There are several other growth factor families produced in the gut whose role in homeostasis control is less well known. Thus, insulin-like growth factors (IGFs) have a minor proliferative effect on the intestine and the fibroblast growth fac- 
tor family has major effects on angiogenesis (its actions may be very important in the healing of ulcers).

\section{ROLE OF GROWTH FACTORS IN IBD}

It is unknown which growth factors are responsible for the several growth phenomena noted in IBD; contenders have been listed above. Certainly the EGF/TGF $\alpha$ molecules are very likely involved in the mucosal hyperplasia that accompanies ulcerative colitis. However, direct evidence of this is lacking. On the other hand, IGF-1 expression is upregulated in fibroblast-like cells of granulation tissue in an animal model of enterocolitis, pointing to a potential role for IGF-1 in the fibrogenic complications associated with IBD (54). A preliminary report describing TGF $\beta$ mRNA levels in patients with varying levels of IBD activity did not find statistically significant differences (55).

However, one phenomenon that does give some insight into the potential role of growth factors in the repair of ulcerative intestinal disease is UACL formation (10). In the crypts surrounding chronic ulcers in the gastrointestinal tract, small buds of cells appear with a distinctive phenotype, mucus-secreting cells that elaborate $\mathrm{D} /$ periodic acid-Schiffpositive neutral mucin rather than the alcianophilic acid mucin usually found in indigenous goblet cells. These buds grow into tubules, which ramify in the lamina propria and form new glandular complexes. A duct then grows upwards through the lamina propria to make contact with the surface via a pore. A photomicrograph of the mature UACL, together with a diagram of the proposed histogenesis, is shown in Figure 4. The system is presumably fed by cells from the parent crypt(s), but in the mature UACL a proliferative zone develops in the duct, which probably feeds cells

\section{REFERENCES}

1. Wright NA, Alison MR. The Biology of Epithelial Populations. Oxford: Clarendon Press, 1984.

2. Cheng $\mathrm{H}$, Leblond CP. Origin, differentiation and renewal of the four main cell types in the mouse small intestine. V. The unitarian hypothesis. Am J Anat 1974;141:537-62.

3. Chang WWL, Leblond CP. A unitarian theory of the origin the three main types of epithelial cells in the mouse small intestine. Anat Rec 1971;269:293.

4. Winton DJ, Ponder BA. Stem cell organization in the mouse small intestine. Proc R Soc Lond [Biol] 1990;241:13-8.

5. Griffiths DR, Davies SJ, Williams D, Williams GT, Williams ED. Demonstration of somatic mutation and crypt clonality by X-linked histochemistry. Nature 1988;333:461.

6. Thompson M, Fleming K, Evans D, Wright NA. Clonal origin of gut endocrine cells in male:female chimaeras demonstrated by combined in situ hybridisation and immunocytochemistry. Development 1990;110:477-81.

7. Pearse AGE, Tabor T. Neuroendocrine embryology and the APUD cell concept. Clin Endrinol 1976;5(Suppl):299-344.

8. Kaftan YT, Wright NA. Studies on the mechanism of goblet cell depletion in experimental colitis. J Pathol 1989;159:75-85.

9. Riddell R. The precancerous phase of ulcerative colitis. In: Morson B, ed. Topics in Pathology. Berlin: Springer, 1978:179-219.

10. Wright NA, Pike C, Elia G. Ulceration induces a novel epidermal growth factor secreting cell lineage in human gastrointestinal stem cells. Nature 1990;343:82-5.

11. Wright NA, Al-Dewachi HF, Watson AJ, Appleton DR. The effect of single and multiple injections of prednisolone on cell population kinetics in the small bowel of the rat. Virchows Arch B Cell Pathol 1978;28:1339-50. upwards towards the surface and downwards into the acinar area (56).

The range of regulatory peptides elaborated by the UACL is really quite extensive. The basal acini contain quantities of immunoreactive EGF, while the whole lineage contains immunoreactive TGF $\alpha$. The acini and the lower duct contain hSP protein and mRNA (Figure 5), while pS2 mRNA and peptide are concentrated in considerable amounts in the upper duct and surface cells (Figure 5), and hITF is present throughout the UACL (53). Lysozyme is also present in the acini, and the UACL is singular in the intestine for expressing MUC 1, as shown by HMFG1 and HMFG2 staining (10).

It has been proposed that this lineage grows adjacent to intestinal and gastric ulcers, and once access to the mucosal surface has been gained, pours its cocktail of growth factors into the local milieu. Because of the mucosal defect, EGF and TGF $\alpha$ at least can bind their receptors on the basolateral side of the surrounding enterocytes or colonocytes.

\section{CONCLUSIONS}

Growth factors have many and manifold influences on the gastrointestinal tract, not just modulating cell proliferation, but also acting on other aspects of physiology. Several of these functions are incriminated in the pathogenetic and healing phenomena that accompany IBD. Now that we can recognize the molecules and know at least their potential functions, we can study their genetic regulation and how their expression and functions contribute to IBD phenomena. Thereby, perhaps, lies the avenue to future therapeutic intervention.

12. Williamson R. Intestinal adaptation 1 . Structural, functional and cytokinetic aspects. N Engl J Med 1978;298:1398-402.

13. Williamson R. Intestinal adaptation 2. Mechanisms of control. N Engl J Med 1978;298:1444-50.

14. Williamson R, Bucholtz TN, Malt RA. Humoral stimulation in small bowel after transection and resection. Gastroenterology 1978;75:249-54.

15. Feldman EJ, Dowling RH, McNaughton J, Peters TJ. Effect of oral versus intravenous nutrition on intestinal adaptation after small bowel resection in the dog. Gastroenterology 1976;70:712.

16. Hanson WR, Rijke RPC, Plaiier HM, et al. The effect of intestinal resection on Thirty-Vella fistula of jejunal and ileal origin in the rat; evidence for a systemic control mechanism of cell renewal. Cell Tissue Kinet 1975;8:135.

17. Miazza, Al-Mukhtar MYT, Salmeron M, et al. The effects of intrarectal installation of hypertonic glucose on cell proliferation in the small intestine. Gut 1985;26:518-24.

18. Al-Mukhtar MYT, Sagor G, Ghatei M, et al. The relationship between endogenous gastrointestinal hormones and cell proliferation in models of intestinal adaptation. In: Robinson J, Dowling RH, Riecken EO, eds. Mechanism of Intestinal Adaptation. Lancaster: MTP Press, 1982:243-53.

19. Clarke RM. "Luminal nutrition" versus "functional workload" as controllers of mucosal morphology and epithelial cell replacement in the rat small intestine. Digestion 1977;68:83-93.

20. Jacobs LR, Taylor BR, Dowling R. Effect of luminal nutrition on the intestinal adaptation following Thirty-Vella fistula in the dog. Clin Sci Mol Med 1975;49:26.

21. Hosomi M, Stace ME, Larussi F, Smith SM, Murphy GM, Dowling $\mathrm{RH}$. Role of polyamines in intestinal adaptation in the rat. Eur J Clin Invest 1987;375:375-85.

22. Goodlad RA, Gregory H, Wright NA. Is polyamine synthesis 
in the proliferative response of the intestinal epithelium to urogastrone-epidermal growth factor. Clin Sci Mol Med 1989;64:595-8.

23. Yarrington JT, Sprinkle DJ, Loude DE, Diekema KA, McCann PP, Gibson JP. intestinal changes caused ny DL- $\alpha$-difluomethylornithine (DFMO), an inhibitor of ornithine decarboxylase. Exp Mol Pathol 1983;39:300-16.

24. Yang P, Baylin SB, Luk GD. Polyamines and intestinal growth: absolute requirement for ODC activity in adaptation during lactation. Am J Physiol 1984;247:G553-7.

25. McCormack SA, Johnson LR. Role of polyamines in gastrointestinal growth. Am J Physiol 1991;260:G695-806.

26. Seidel ER, Haddox MK, Johnson LR. Ileal mucosal growth during intraluminal infusion of ethylamine or putrescine. Am J Physiol 1985;249:G434-8.

27. Ratcliffe B, Lee CY, Wright NA, Goodlad RA. Dietary fibre and the gastrointestinal epithelium; differential response in the stomach small intestine and colon of conventional and germ-free rats. In: Waldron KW, ed. Food and Cancer Prevention. Cambridge: Royal Society of Chemistry, 1990:364-8.

28. Bloom S, Polak J. Hormonal pattern of intestinal adaptation. In: Polak J, Bloom SR, Daly M, Wright NA, eds. Structure of the Gut. Ware: Glaxo, 1982:409-19.

29. Chinery R, Goodlad RA, Wright NA. The effects of fibre on the expression of growth factors in the colon. J Nutrition. (In press)

30. Schaudies P, Grines J, Wray HL, Koldovsky O. Identification and partial characterization of multiple forms of biologically active EGF in rat milk. Am J Physiol 1990;s?59:G1056-61.

31. Goodlad RA, Raja KB, Peters TJ, Wright NA. Effects of urogastroneepidermal growth factor on intestinal brush border enzymes and mitotic activity. Gut 1991;32:994-8.

32. Thompson JF. Specific receptors for epidermal growth factor in rat intestinal microvillus membranes. Am J Physiol 1988;254:G429-35.

33. Scheving LA, Shiurba RA, Nyguyen TD, Gray GM. Epidermal growth factor receptor of the intestinal enterocyte. Localization to laterobasal but not brush border membrane. J Biol Chem 1989;264:1735-41.

34. Weaver LT, Gonnella PA, Israel EJ, Walker WA. Uptake of epidermal growth factor by the small intestinal epithelium of the fetal rat. Endocrinology 1990;98:828-37.

35. Rao RK, Thornburg W, Korc M, Matrisian SM, Magun BE, Koldovsky O. Processing of epidermal growth factor by suckling and adult rat intestinal cells. Am J Physiol 1986;250:G850-5.

36. Reeve JR, Richards RC, Cooke T. The effects of intracolonic EGF on mucosal growth and experimental carcinogenesis. Br J Cancer 1991;63:223-6.

37. Goodlad RA, Wilson TJ, Lenton W, Gregory H, Wright NA. Intravenous but not intragastric urogastrone-EGF is trophic to the intestine of parenterally-fed rats. Gut 1987;28:573-82.

38. Konturek SJ, Ciezkowski M, Jaworek J. Effects of epidermal growth factor on gastroduodenal secretions. Am J Physiol 1984;246:G580-6.

39. Koyama D, Podolsky DK. Differential expression of transforming growth factors $\alpha$ and $\beta$ in rat intestinal cells. J Clin Invest 1989;83:1768-77.
40. Opleta-Madsen K, Hardin J, Gall DG. Epidermal growth factor upregulates intestinal electrolyte transport. Am Phys Soc 1991;G817-24.

41. Tomasetto C, Rio M-C, Gautier C, et al. hSP, the domain-duplicated homologue of $\mathrm{pS} 2$ protein, is expressed with $\mathrm{pS} 2$ in the stomach but not the breast. EMBO J 1990;92:407-14.

42. Delarco JE, Todaro GJ. Growth factors from murine sarcoma virus-induced cells. Proc Natl Acad Sci USA 1978;75:4001-5.

43. Moses HL, Branum E, Proper J, Robinson RA. Transforming growth factor production by chemically-transformed cells. Cancer Res 1981;41:2842-8

44. Coffey RJ, Snipes NH, Bascom CC, et al. Growth modulation of mouse keratinocytes by transforming growth factors. Cancer Res 1988;48:1596-602.

45. Hoosein NM, Brattain DE, MacKnight MK, Levine AE, Brattain MG. Characterization of the inhibitory effects of transforming growth factor- $\beta$ on a human colon carcinoma cell line. Cancer Res 1987;47:2950-4

46. Chakrabarty S, Tobon A, Varani G, et al. Induction of carcinoembryonic antigen secretion and modulation of protein secretion/ expression and fibronectin/lamina expression in human colon carcinoma cells by transforming growth factor-beta. Cancer Res $1988 ; 48: 4659$.

47. Barnard J, Coffey RJ. Transforming growth factor P. In: Walsh JH, Dockray GJ, eds. Gut Peptides; Biochemistry and Physiology. New York: Raven Press, 1994:615-63.

48. Leof E, Proper J, Goustin AS, Shipley GD, DiCorleto PE, Moses HL. Induction of $\mathrm{c}$-sis mRNA and activity similar to platelet derived growth factor by transforming growth factor- $\beta$; a proposed model for indirect mitogenesis involving autocrine activity. Proc Natl Acad Sci USA 1986;83:2453-7.

49. Suemori S, Ciacci C, Podolsky DK. Regulation of transforming growth factor expression in rat intestinal epithelial cell lines. J Clin Invest 1991;67:2216-21.

50. Freemont P, Brown G, Gorman MA, et al. The three-dimensional structure of PSP as shown by X-ray crystallography. Proc Natl Acad Sci USA 1995;91:1084-8.

51. Carr M, Lane A, Reeney J, et al. The solution structure of PSP demonstrated by 2D NMR. Proc Natl Acad Sci USA. (In press)

52. Thim L, Thomsen J, Christensen M, Jorgensen KE. The amino acid sequence of pancreatic spasmolytic polypeptide. Biochem Biophys Acta 1985;825:410-8

53. Poulsom R, Wright NA. The trefoil peptide family. Am J Physiol 1993;265:G205-18.

54. Zimmerman EM, Sartor RB, McCall RD, Pardo M, Spencer EM, Lund PK. Insulin-like growth factor 1 and interleukin $1 \mathrm{~b}$ mRNA in a rat model of granulomatous enterocolitis and hepatitis. Gastroenterology 1993;105:399-409.

55. Rossiter G, Podolsky DK. Expression of transforming growth factor $\alpha$ and $\beta$ in colonic mucosa in ulcerative colitis. Gastroenterology 1990;98:A471.

56. Ahnen D, Poulson R, Stamp G, et al. The ulcer-associated cell lineage shows the histogenetic programme of Brunners glands but evolves the proliferative organization of the gastric gland. J Pathol 1994;173:213-9. 


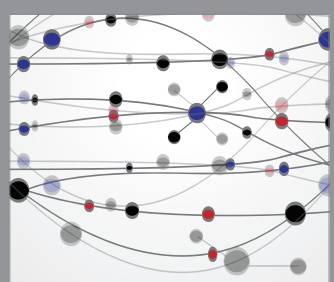

The Scientific World Journal
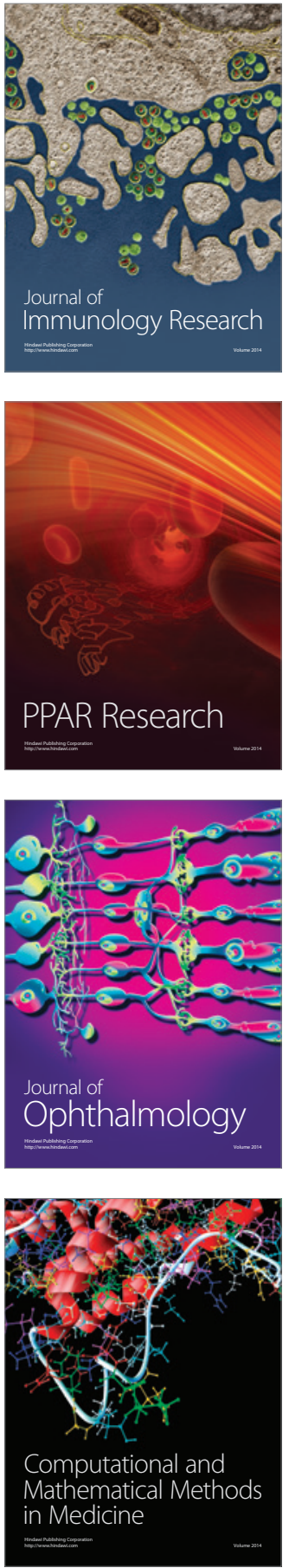

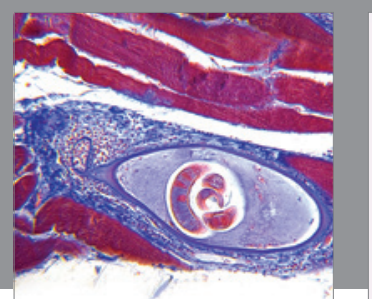

Gastroenterology Research and Practice

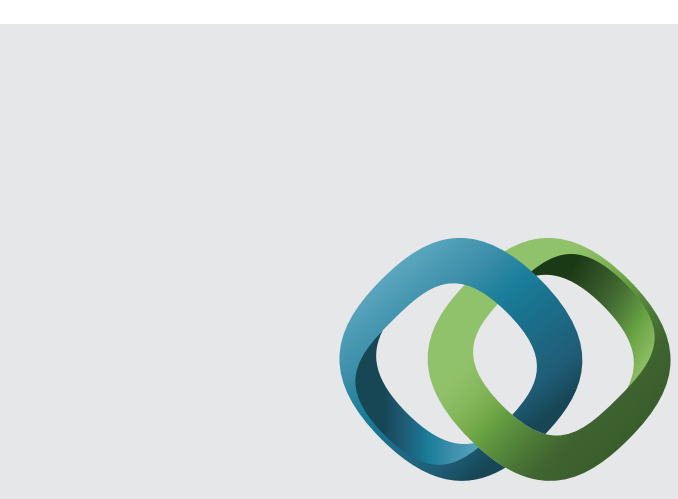

\section{Hindawi}

Submit your manuscripts at

http://www.hindawi.com
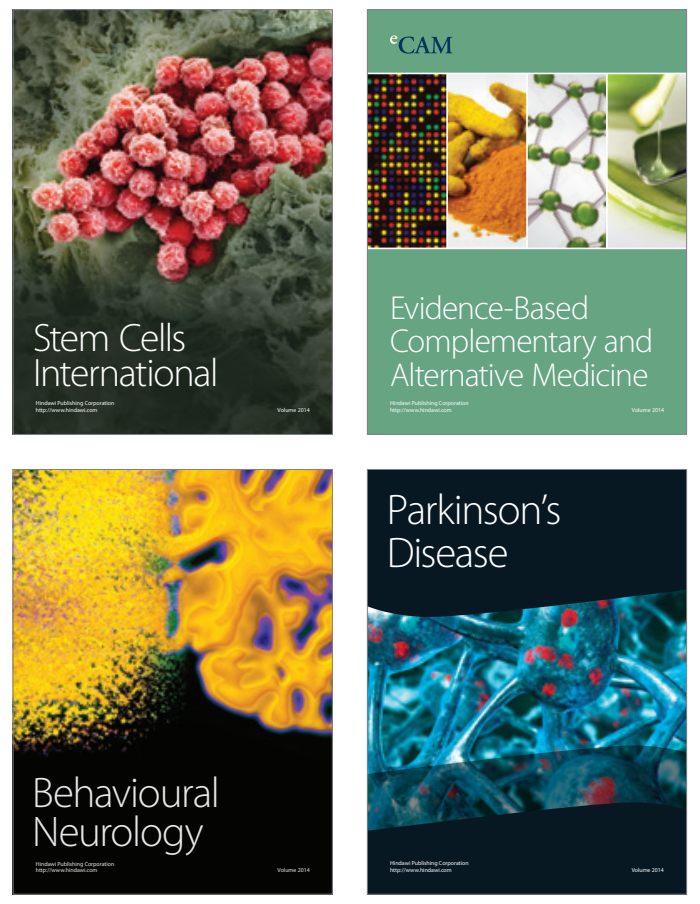
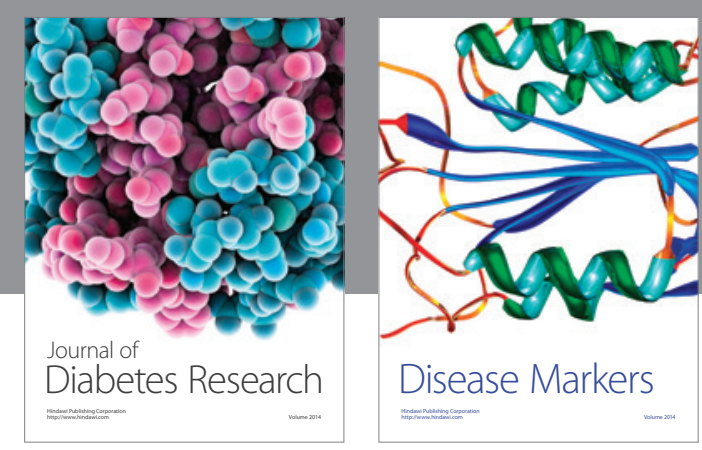

Disease Markers
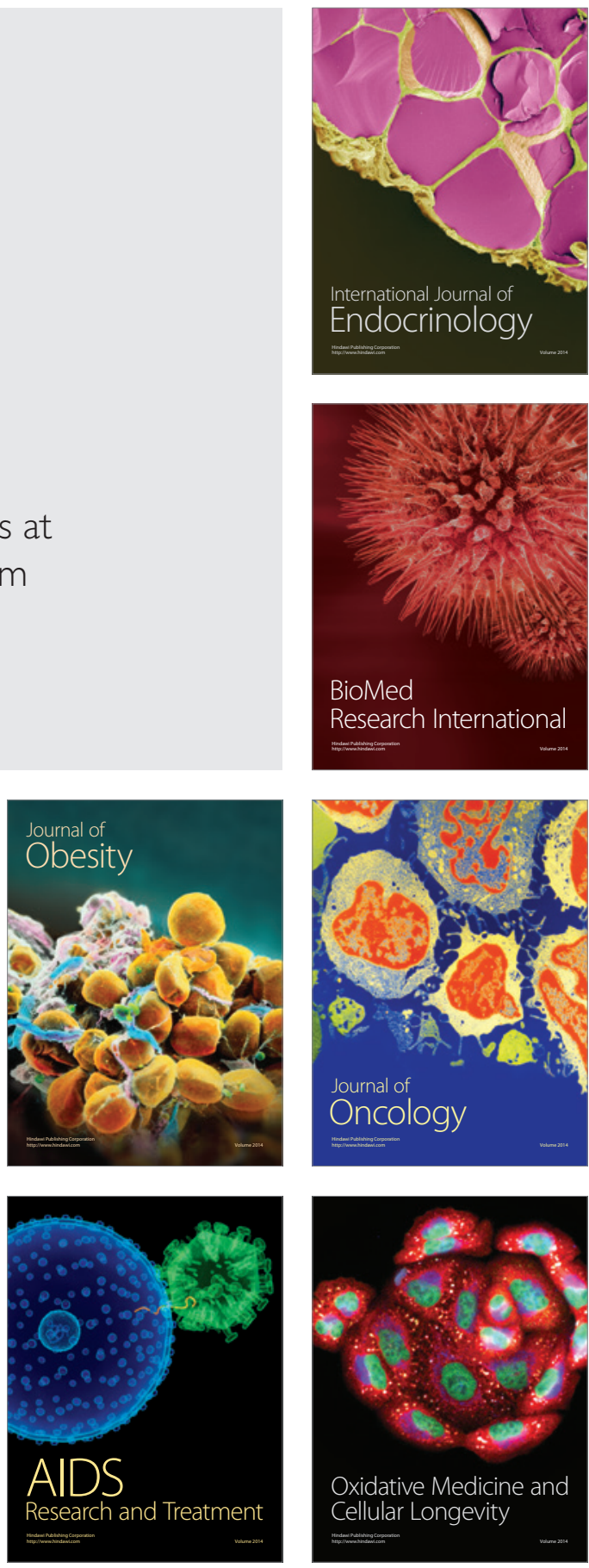